\title{
Investigating Turkish Pre-service Science Teachers' Moral Reasoning in Genetics related Socioscientific Issues
}

\author{
Ümran Betül Cebesoy ${ }^{*}$ \\ ${ }^{1}$ Department of Science Education, Faculty of Education, Usak University, Usak, Turkey \\ *Corresponding author: ubetulcebesoy@gmail.com
}

\begin{abstract}
In this study, Turkish pre-service science teachers' moral reasoning patterns and the factors which influence their decisions while discussing genetics-related socio-scientific issues (SSI) were investigated. A basic qualitative approach was adopted for this purpose. Seven third-grade pre-service science teachers enrolled in the study. Semi-structured interviews for different genetics related SSI were conducted. The results revealed that decisions were generally based on the consequences of genetic applications (consequentialist) or based on moral principles or prescripts (principle-based). Most participants used consequencebased moral reasoning in their decisions, while principle-based moral reasoning was less used. They also used emotion-based moral reasoning. Their decisions were influenced by emotions, including empathy or sympathy toward the characters, or the unborn baby, in the scenarios. Additional and varied factors, including legal, ethical, economic, and technological concerns, were revealed as influential. Participants' decisions were also shaped by their own experiences, media resources, and faith in science. The implications for science teacher education programs are discussed.
\end{abstract}

Keywords Decision-making, Genetics, Pre-service science teachers, Socioscientific issues

\section{INTRODUCTION}

Scientific literacy is essential for several reasons: First, it helps people deal with the issues and challenges in their daily lives. It also enhances making informed decisions when confronted with their health, lifestyles, or consumption habits by considering scientific understanding. Second, it prepares individuals as knowledgeable civic decision-making participants (National Academies of Sciences, Engineering, and Medicine, 2016; Organisation for Economic Co-operation and Development [OECD], 2012). Thus, science education has long desired to support scientific literacy development (Bossér, Lundin, Lindahl, \& Linder, 2015). On the other hand, socioscientific issues (SSI, hereafter) are considered an indispensable part of scientific literacy (Zeidler \& Keefer, 2003; Sadler, 2004a). SSI includes a wide range of socially controversial issues linked to science (Sadler \& Zeidler, 2005; Sadler, 2004a). These issues are ill-structured and open-ended, often requiring negation by considering multiple perspectives (Chang Rundgren \& Rundgren, 2010; Sadler \& Donnely, 2009; Zeidler, Sadler, Applebaum, \& Callahan, 2009; Zeidler, 2003). A wide range of social issues which are connected to science, environment, and technology are considered as SSI: Cloning, gene therapy, stem cell research, genetic engineering, nuclear power plantation, and global climate change (Lee, Chang, Choi, Kim \& Zeidler, 2012; Sadler \& Zeidler, 2005; 2004; Sadler \& Donnely, 2009). While dealing with the issues mentioned above, individuals engage in the decision-making process (Fowler \& Zeidler, 2016). While making-decisions in SSI, individuals need to consider ethical and moral dimensions in addition to the scientific content (Bell \& Lederman, 2003; Sadler, 2004a, 2004c). Zeidler \& Keefer (2003) indicated that morality could not be omitted while discussing and negotiating SSI.

One of the essential topics of SSI is genetics related issues. Genetics is developing fast with current technological innovations, giving rise to various controversies (Gericke \& Smith, 2014). Thus, it is frequently used by researchers (i.e., Sadler \& Zeidler, 2004; 2005). Also, it provides context for exploring participants' use of morality while making-decisions in SSI. For instance, Sadler and Zeidler (2004) explored college students' decision making on genetic engineering issues. The results showed that college students made decisions by referring

Received: 10 September 2020

Revised: 22 November 2020

Published: 28 November 2020 
to consequence-based and principle-based moral reasoning patterns. The researchers also revealed that emotions and intuition were influential in their decisions. Their choices were also influenced by a wide range of factors, including family bias, personal experience, religion, extra background knowledge, and pop culture. In another study, Sadler (2004a) explored 30 college students' moral sensitivity enrolling in biology and psychology courses using two genetic engineering issues (cloning and human gene therapy). The results revealed that participants had a variety of moral considerations when confronted with genetics related SSI. Participants were concerned about individuals' health, and well-being and the sufferings that the people would go through. Besides health-related reasons, they were concerned about proposed genetic technologies were altering the natural order. Another concern identified was the slippery slope arguments indicating using the genetic application in one proper context might lead to its usage in other unacceptable contexts. Also, minor concerns such as doctors' responsibilities, patients' right to treatment, making decisions for someone who cannot decide on his/her own, and creating social classes among society were revealed. Topçu, Yılmaz-Tüzün, and Sadler (2011) explore 39 'Turkish pre-service science teachers' informal reasoning explored in different SSI, including gene therapy, human cloning, and global warming. They revealed pre-service science teachers' multidimensional informal reasoning patterns, including rationalistic, emotive, and intuitive, interwoven with each other. The results also showed that pre-service science teachers' moral reasoning was influenced by different factors, including personal experiences, social, moral, and ethical considerations. In another recent study, Cebesoy (2014) explored science teachers' decision-making skills in genetics-related SSI. The researcher found out that many factors influenced science teachers' decisions on genetics-related SSI. While moral considerations were the most influential factor, other factors including economic, legal, technological, and religious concerns, were also significant. Sadler and Donnely (2009) explored high school students' argumentation quality in genetic engineering issues and revealed that students considered genetic engineering issues as moral problems.

The abovementioned studies conducted with college students (Sadler \& Zeidler, 2004; Sadler, 2004b), preservice science teachers (Topcu, Yilmaz-Tuzun \& Sadler, 2011), science teachers (Cebesoy, 2014) or with students (Sadler \& Donnelly, 2006). These studies showed the importance of including the morality dimension while dealing with SSI. Besides, studies also reported that SSIbased teaching has fruitful outcomes (i.e., Eggert, Ostermayer, Hasselhorn, \& Bögeholz, 2013; Gresch, Hasselhorn, \& Bögeholz, 2017). For instance, studies reported that SSI-based teaching improved students' decision-making skills (Eggert et al., 2013; Gresch et al.,
2017). However, Ozden (2020) indicated that students use low-quality reasoning while discussing SSI, which shows the need to include SSI-based teaching into the science classes, which is frequently emphasized in the literature (Sadler \& Donnelly, 2006; Ozden, 2020; Zohar \& Nemet, 2002). Here, teachers' and future teachers' skills to introduce SSI-based teaching into their classes come to the fore. Previous research indicated that teachers' beliefs and attitudes towards SSI influence their SSI-based education (Khishfe, 2014; Walker \& Zeidler, 2007). However, the literature reports many teachers perceived SSI-based teaching as challenging (Sadler, Amirshokoohi, Kazempour, \& Allspaw, 2006; Rundgren \& Chang Rundgren, 2018). Many teachers were reported to feel uncomfortable introducing ethics and values along with scientific content (Sadler et al. 2006), to have lack of knowledge (Aivelo \& Uitto, 2019), and lack of confidence for dealing with SSI (Bryce \& Gray, 2004).

Making informed decisions on controversial issues does not develop naturally unless training in decision-making is provided to the students (Eggert et al., 2013; Gresch et al., 2017; Hsu \& Lin, 2017). Thus, the teachers and future teachers are expected to develop their students' decisionmaking skills in the controversial issues to prepare them for their future roles as active individuals of society (Bingle \& Gaskel, 1994). At this point, science teacher education programs play a crucial role in developing science teachers' SSI-based practices (Sadler et al. 2006). However, when the role of teacher education programs is considered, there seems to be one crucial unanswered question: How do future teachers decide these controversial issues? This question remains unanswered while dealing with genetics related controversies like gene therapy or other genetics applications. Thus, the present study aims to explore preservice science teachers' decision-making processes in genetics related to controversial issues. Specifically, two research questions guided this study:

1. What are the moral reasoning patterns that pre-service science teachers refer to while handling genetics related controversial issues?

2. What other factors (other than moral reasoning) influence pre-service science teachers' decision-making in genetics related controversial issues?

\section{METHOD}

This study adopted the basic qualitative generic qualitative approach (Kahlke, 2014; Merriam, 2009). In this approach, the researcher focuses on "(1) how people interpret their experiences, (2) how they construct their worlds, and (3) what meaning they attribute to their experiences" (Merriam, 2009). As a result, the studies adopting this approach are not directed by a set of grounded assumptions in other forms of qualitative methodologies like grounded theory or ethnography (Caelli, Ray, \& Mill, 2003). This method seeks to 
understand people's interpretation of the world (Kahlke, 2014). Likewise, this study explored how pre-service science teachers interpret a series of genetics related to controversial issues based on their worldviews and experiences.

\subsection{Participants}

Seven third-grade pre-service science teachers who enrolled at a large public university in Turkey's central Anatolia region voluntarily participated in the study. Typical purposive sampling was used for determining the participants (Maxwell, 1997; Teddlie \& Tashakkori, 2009). In this technique, the researcher collects data from particular settings or participants to provide vital information for the study (Maxwell, 1997). In this study, third-grade pre-service science teachers were chosen purposefully. They had completed a series of formal courses about biology, genetics, and biotechnology in their previous semesters and thus were considered as informed about the topics being investigated in the study. The researcher explained the study's aim in a course and invited all the third-grade pre-service science teachers (a total of 32 students at the time) for an interview in a private office. Willingness to participate in the study and the grade level was the only criteria for participant selection. Seven preservice teachers (all were females) agreed to join the study voluntarily.

\subsection{Data collection and Issue Selection}

The semi- or full-structured interviews are a standard data collection tool in the basic qualitative approach (Percy, Kostere, \& Kostere, 2015). Semi-structured interviews conducted by the researcher collected the data in this study.

The interviews focus on a series of genetics related to controversial issues, including genetics applications. The researcher mainly chose these scenarios for two reasons: First, one of the objectives of the 8th-grade Turkish primary science curriculum stated that development of students' discussion of controversial issues arising from future genetics and biotechnology applications (Ministry of National Education [MoNE], 2018). As a result, the four scenarios used in the present study included a discussion of genetics applications. Second, they are pedagogically appropriate and used in previous studies conducted with both science teachers (Cebesoy, 2014) and pre-service science teachers (Karisan \& Cebesoy, 2020) in Turkey.

The researcher conducted semi-structured interviews with participants in a private office. The interviews lasted between 37 minutes to 62 minutes and audio recorded after taking permission of the participant. Each interview began with a brief description of the scenario, and the participant handled the procedures if she wanted to read it herself. Then, the participants were asked to answer a series of questions in each scenario. The scenarios were briefly explained below:

Scenario 1: Fetal tissue transplantation
This scenario was developed by Bell and Lederman (2003). It begins with a fictitious newspaper article mentioning Dr. Acar's treatment (fetal tissue transplantation) of Alzheimer's disease using unborn fetuses' brain cells. Suzan, in her late 30s, had an unexpected pregnancy considers aborting the fetus and donating it to Dr. Acar's study to be used for her father's treatment. Should she abort the fetus for her father's treatment?

Scenario 2: Cystic fibrosis

This scenario was developed by Zohar and Nemet (2002). There is a brief description of cystic fibrosis disease and the symptoms of the disease. Two treatment options are only in the clinical trials phase, with no success at that moment. A couple whose brothers had cystic fibrosis disease learns that they are expecting a baby. Should the couple decide to end the pregnancy?

Scenario 3: Huntington Disease

This scenario was developed by Zohar and Nemet (2002) to show a brief description of Huntington's disease and the symptoms of the disease. There is no successful treatment at that moment. A fictitious character, Lale, whose father was diagnosed with Huntington's Disease, learns that she is pregnant. Should she decide to end the pregnancy?

Scenario 4: Gene therapy

This scenario was developed by Sadler and Zeidler (2004). There is a brief description of gene therapy and how it could treat Huntington's disease and enhance human intelligence. Should gene therapy be used for these purposes?

Each scenario included a series of questions to get a more in-depth understanding of pre-service science teachers' perspectives. Each scenario was translated and adapted into Turkish. Experts checked the equivalence of original and translated versions in biology education and science education. A pilot study was done with one science teacher to check the appropriateness of the given information's language and sufficiency.

\subsection{Data Analyses}

The data were transcribed verbatim. Thematic analysis (Braun \& Clarke, 2013) was used to identify the data's familiar themes. We preferred to use theoretical thematic analysis among different thematic analysis types as there were some predetermined codes and themes in the previous studies. These predetermined codes and themes were derived from previous studies (Bell, 1999; Bell \& Lederman, 2003; Sadler, 2004a; Sadler \& Zeidler, 2004; Topcu, 2008; Zohar \& Nemet, 2002). Then, we applied the quantizing approach (transforming qualitative data into numeric values) (Miles \& Huberman, 1994) to determine which theme was more emergent in the data.

Participants' morality-based decisions in geneticsrelated scenarios were analyzed by Sadler and Zeidler's (2004) framework (see, Figure 1). 
Table 1 The patterns of consequentialist moral reasoning (adapted from Sadler \& Zeidler, 2004)

\begin{tabular}{ll}
\hline $\begin{array}{l}\text { Consequentialist moral } \\
\text { reasoning }\end{array}$ & Description \\
\hline $\begin{array}{l}\text { Health improvement } \\
\text { Slippery slope }\end{array}$ & $\begin{array}{l}\text { Statements that emphasize the importance of improvement in the health of individuals } \\
\text { Statements that indicate concerns about the allowance of the application of genetics technologies } \\
\text { in one acceptable context would lead to the use of that technology in unacceptable contexts. }\end{array}$ \\
$\begin{array}{l}\text { Societal betterment } \\
\text { Social stratification }\end{array}$ & $\begin{array}{l}\text { Statements that imply the use of genetic technologies will improve society overall. } \\
\text { Statements showing concerns regarding that use of genetic technologies may segregate a } \\
\text { population by creating classes of "genetic haves" and "genetic have nots" }\end{array}$ \\
Diversity & $\begin{array}{l}\text { Statements that indicate participants' concerns about the genetics application will reduce the } \\
\text { diversity and will cause erosion of diversity }\end{array}$ \\
\hline
\end{tabular}

Table 2 The patterns of principle-based moral reasoning (adapted from Sadler \& Zeidler, 2004)

\begin{tabular}{ll}
\hline $\begin{array}{l}\text { Principle-based moral } \\
\text { reasoning }\end{array}$ & Description \\
\hline Taking human life & $\begin{array}{l}\text { Statements showing concerns regarding the status of an embryo as a human being. Therefore, } \\
\text { sacrificing embryos violates the principle of taking human life }\end{array}$ \\
$\begin{array}{l}\text { Means to an end } \\
\text { Disrupting natural order }\end{array}$ & $\begin{array}{l}\text { Statements showing concerns about the use of embryos as resources or tools when needed } \\
\text { Statements showing concerns regarding the applications of genetics change natural process } \\
\text { unexpectly }\end{array}$ \\
Parental rights & $\begin{array}{l}\text { Statements that indicate that a fetus does not have rights, it is parents' responsibility to decide } \\
\text { whether to abort or not abort the fetus. }\end{array}$
\end{tabular}

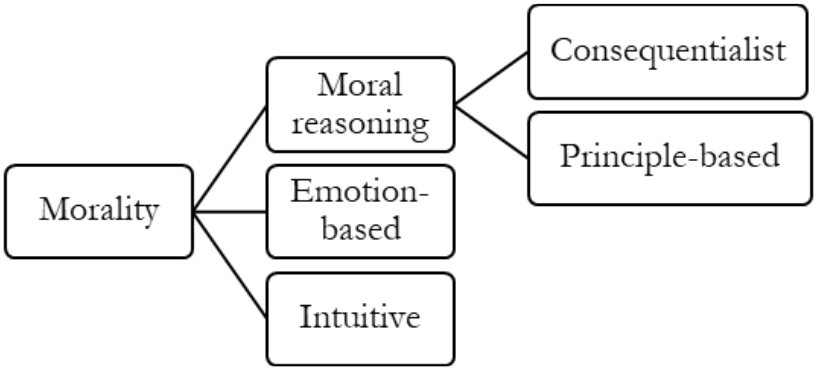

Figure 1 The morality aspect of Socioscientific Issues (Adapted from Sadler \& Zeidler, 2004)

While making decisions in genetics related SSI, participants might display three categories of moral choice as moral reasoning, emotive-based, and intuitive-based. According to Sadler and Zeidler (2004), moral reasoning can also be classified under two subheadings: (1) consequentialist moral reasoning and (2) principal based moral reasoning. While consequentialist moral reasoning was based on their utilitarian analyses of the consequences of processes in the genetics applications, a principal-based ethical decision was mainly based on the moral principles or prescripts. Under some circumstances, participants' decisions might be found on neither consequences nor principles. Here, their choices were influenced by emotions such as empathy or sympathy towards the scenarios' fictitious characters. Lastly, in moral intuition, participants expressed their opinions but did not explain their decisions.

While exploring pre-service science teachers' consequentialist and principal-based moral reasoning, some patterns were revealed based on the participants' responses to genetics related SSI during the interview. The patterns of consequentialist moral reasoning were presented in Table 1, and the patterns of principle-based moral reasoning were shown in Table 2, respectively.

The researcher coded participants' responses to the interviewer's questions. After coding, the frequency of appearance of each pattern was calculated. To ensure the participants' anonymity, each participant was given an ID number (from 1 to 7). While 'PT' refers to pre-service science teacher, PT-5 refers to the fifth pre-service science teacher in the study. Different scenarios were coded as S-1 for fetal tissue transplantation, S-2 for Cystic fibrosis, S-3 for Huntington's Disease, and S-4 for gene therapy scenarios.

\subsection{Trustworthiness of the Study}

The trustworthiness of the study was ensured by using several techniques. First, investigator triangulation was used to prevent misinterpretation of the data and researcher bias (Archibald, 2016; Guion, 2002). For this, the researcher coded the first three pre-service science teachers' audio-transcribed data based on the framework developed by Sadler and Zeidler (2004). Then, another researcher who has expertise in science education and socioscientific issues coded the same data. Lastly, both researchers assembled to discuss the framework and built a consensus on the analysis framework. Inter-coder reliability (Miles \& Huberman, 1994) was calculated to show the compatibility and the agreement between two coders by using the formula:

Total number of agreements/ (total number of agreements + the total number of disagreements)

This value was calculated as $86 \%$. Then, the researcher completed the rest of the data analysis. 
Table 3 The total number of statements with respect to each reasoning pattern

\begin{tabular}{|c|c|c|c|c|c|c|}
\hline & $\begin{array}{l}\text { Frequency } \\
\text { (n) }\end{array}$ & $\begin{array}{l}\text { Percentage } \\
(\%)\end{array}$ & & Subdimensions & $\begin{array}{l}\text { Frequency } \\
\text { (n) }\end{array}$ & $\begin{array}{l}\text { Percentage } \\
(\%)\end{array}$ \\
\hline \multirow[t]{3}{*}{$\begin{array}{l}\text { Moral } \\
\text { reasoning }\end{array}$} & 228 & 78.89 & Moral reasoning & $\begin{array}{l}\text { Consequence- } \\
\text { based }\end{array}$ & 116 & 50.88 \\
\hline & & & & Principle-based & 43 & 18.86 \\
\hline & & & $\begin{array}{l}\text { Moral emotion- } \\
\text { based }\end{array}$ & & 69 & 30.26 \\
\hline Other factors & 61 & 21.19 & & & & \\
\hline Total & 289 & 100 & & & 228 & 100 \\
\hline
\end{tabular}

Table 4 Pre-service science teachers' consequentialist moral reasoning patterns

\begin{tabular}{|c|c|c|}
\hline $\begin{array}{l}\text { Consequentialist } \\
\text { moral reasoning }\end{array}$ & Frequency & Sample Excerpts \\
\hline \multirow{3}{*}{ Health improvement } & 73 & $\begin{array}{l}\text { 'I think there is no problem to use fetus in this treatment [referring fetal tissue } \\
\text { transplantation]. The priority for me is this method is used for treating the patient.' } \\
\text { (PT-3, S-1) }\end{array}$ \\
\hline & & $\begin{array}{l}\text { 'If they do not want the fetus, they can consider aborting the fetus as they need this } \\
\text { treatment [referring to fetal tissue transplantation]. I think, this treatment option can be } \\
\text { considered.' (PT-6, S-1) }\end{array}$ \\
\hline & 15 & $\begin{array}{l}\text { 'The only thing that comes to my mind with the possible treatment options offered in } \\
\text { the scenario is the accessibility of the treatment by all people who do need it. I mean if } \\
\text { some people can access and others could not, then, there would be a stratification } \\
\text { among society who can afford or access the treatment and who cannot.' (PT-3, S-2) }\end{array}$ \\
\hline Societal betterment & 12 & $\begin{array}{l}\text { 'With this method [referring to gene therapy], the next generations will be healthy } \\
\text { which is beneficial for the society as a whole.' (PT-5, S-4) }\end{array}$ \\
\hline Slippery slope & 12 & $\begin{array}{l}\text { 'I think parents should be given to change their children's genes in case of diseases. } \\
\text { Except for diseases, using gene therapy for beauty or intelligence is worrisome.' (PT-7, } \\
\text { S-4) }\end{array}$ \\
\hline Diversity & 4 & $\begin{array}{l}\text { 'I believe that society needs all kinds of people except smarter people. I think we do } \\
\text { need farmers as much as we need scientists as a society. Thus, there should be some } \\
\text { kind of diversity among levels of intelligence.' (PT-2, S-4) }\end{array}$ \\
\hline
\end{tabular}

\section{RESULT AND DISCUSSION}

The four scenarios regarding genetics related SSI confronted pre-service science teachers with various opinions during the interviews. First, pre-service science teachers' moral reasoning patterns were examined. Then, what kind of considerations other than ethical considerations influenced their decisions and opinions were examined.

\subsection{Pre-service Science Teachers' Moral Reasoning Patterns}

A total of 289 statements were coded. While 228 of the comments were coded under the moral reasoning theme $(78.89 \%), 61$ were coded as influencing factors $(21.19 \%)$. Among 228 statements, 159 statements (69.74) were coded under moral reasoning, and 69 comments $(30.26 \%)$ were coded under moral-emotion based reasoning (see table 3 for the frequency and percentages). The results revealed that the pre-service science teachers in this study showed two moral reasoning categories while making decisions about genetics related SSI: (a) Moral reasoning and (b) Moral-emotion based reasoning. While examining their moral reasoning patterns, two significant themes also emerged: Pre-service science teachers either made decisions based on the consequences of genetics applications (consequentialist) or based on the moral principles or prescripts (principle-based).

Pre-service science teachers' consequentialist moral reasoning patterns

Pre-service science teachers indicated the consequences of genetics applications while making decisions in genetics related SSI. They evaluated the benefits and advantages as well as disadvantages of genetics applications presented in the scenarios. Thus, their reasoning was coded as consequentialist moral reasoning. Moreover, pre-service science teachers' consequentialist moral reasoning patterns were also explored, and other sub-themes emerged in the data. As mentioned in the method section, the researcher delineated which sub-themes were more emergent based on the frequency analysis. Table 4 shows the sub-themes emerged in the consequentialist moral reasoning patterns:

Pre-service science teachers demonstrated a wide range of consequentialist patterns in their decisions while dealing with SSI genetics. When Table 4 was examined, it could be seen the major sub-theme that emerged in the data was health improvement. Pre-service teachers favored the importance of health while making decisions. Even though health improvement was vital for them to support genetics applications, some were concerned that these genetics 
Table 5 Pre-service science teachers' principle-based moral reasoning patterns

\begin{tabular}{|c|c|c|}
\hline $\begin{array}{l}\text { Principle-based } \\
\text { moral reasoning }\end{array}$ & Frequency & Sample Excerpts \\
\hline Parental rights & 16 & $\begin{array}{l}\text { 'I think what family goes through is more important. Thus, I believe that the family has the } \\
\text { right to choose what is best for their unborn baby.' (PT-1, S-3) } \\
\text { 'If parents were allowed to change their children's genes, their responsibility would } \\
\text { definitely change, in fact, it would increase. Thus, parents should not be given the right to } \\
\text { use gene therapy to increase the intelligence of their children.' (PT-4, S-4) } \\
\text { 'We have no rights over individuals. Thus, parents should not able to let their fetus be used } \\
\text { in this experimental research [referring to fetal tissue transplantation].' (PT-5, S-1) }\end{array}$ \\
\hline Taking human life & 14 & $\begin{array}{l}\text { 'A fetus even in its embryo stage has the right to live. It makes no sense to abort the fetus, } \\
\text { just as it might be sick.' (PT-2, S-2) } \\
\text { 'While deciding on abortion, Lale [referring to the fictitious character], she would be taking } \\
\text { the fetus' right to live.' (PT-4, S-3) }\end{array}$ \\
\hline Means to an end & 7 & $\begin{array}{l}\text { 'Suzan [referring to the fictitious character] should not be allowed to abort the fetus if she } \\
\text { only intends to donate it to an experimental trial.' (PT-3, S-1) } \\
\text { 'If the main aim is to provide tissue for the experimental trial, this does not make sense. } \\
\text { Then, she would be killing her unborn baby for her father who already lived for a certain } \\
\text { time.' (PT-6, S-1) }\end{array}$ \\
\hline $\begin{array}{l}\text { Disrupting natural } \\
\text { order }\end{array}$ & 6 & $\begin{array}{l}\text { 'We should not interfere with nature. We are evolving more and more as time passes. As } \\
\text { we complete our evolution, our intelligence will also develop more. I think this process } \\
\text { should be natural and there should be no external intervention.' (PT-1, S-4) }\end{array}$ \\
\hline
\end{tabular}

applications might create social classes (those who can access the genetics applications and those who cannot) reflected in the social stratification theme. Another theme was the slippery slope, which indicated that pre-service science teachers indicated that genetic engineering allowance in one proper context (i.e., use it for diseases) might lead to unexpected consequences (i.e., use it for beauty or intelligence). Lastly, some statements highlighted the importance of heterogeneity in society, coded under the diversity theme. These pre-service teachers stated that there should be diversity in society as society needs different talents and different needs.

Pre-service teachers' principle-based moral

\section{reasoning patterns}

In addition to pre-service teachers' consequentialist moral reasoning patterns, the pre-service teacher sometimes made decisions based on some prescripts or ethical principles such as the right to live or natural order. With this respect, their decisions were considered independent of genetics applications' consequences but dependent on some moral rules. Here, four sub-themes emerged reflecting the principle-based moral reasoning theme: (a) parental rights, (b) taking human life, (c) a means to an end, and (d) distrusting natural order. Table 5 shows the most frequently stated sub-themes emerged in the data:

According to Table 5, the most emergent theme was parental rights. While some pre-service science teacher (i.e., PT-1) expressed that parents had the right to choose what is the best for their children, other pre-service teachers (i.e., PT-4 and PT-5) reflected that parents should not have the right to change their children's genes by using gene therapy to make them smarter (S-4) or to let their unborn baby (fetus) to be used in experimental research (S-1). Another emergent theme was taking human life, indicating participants' concerns as embryo's status and rights. They considered the fetus a human being and thus, believed that the fetus has the right to live. Some participants had concerns about using the fetus as a tool or resource for the scenario's treatment (S-1). They perceived the fetus's use in an experimental trial as unexpectable if the fetus is only perceived as a tool for the trial. Lastly, some participants indicated that there should be no external intervention to the natural order, which was coded under a disturbing natural order theme. These participants believed that there is an order in the natural which needs to be undisrupted.

\subsection{Pre-service Science Teachers' Emotion-Based Reasoning Patterns}

Participants' decisions about genetics related SSI did not always rely on consequent reasons or principles. Preservice science teachers sometimes were influenced by emotions, including empathy or sympathy toward the characters or the unborn baby in the scenarios. Sixty-nine statements $(30.26 \%)$ were coded as emotive based. The parents considered donating the fetus for an experimental trial for their father, who has Parkinson's disease. In Cystic Fibrosis and Huntington disease scenarios, the symptoms are severe and mostly fatal. Sample excerpts are provided below:

'If Lale [referring to the fictitious character] gave birth to ber child when the child turned to be the 50s, his/ herparents might not be with him what I mean, and they could be deceased. I think it as myself. Then, you are giving birth to someone with whom you will not be by the side. That is a responsibility. I consider making an abortion with this respect.' (PT-3, S-3)

I think it is a bad feeling to know when a person will die. Thus, it is better to abort the fetus before it is too late.' (PT-1, S-2) 
Table 6 The factors influencing pre-service science teachers' decision-making processes

\begin{tabular}{|c|c|c|c|}
\hline $\begin{array}{l}\text { Influencing } \\
\text { factors }\end{array}$ & Description & Frequency & Sample Excerpts \\
\hline Legal concerns & $\begin{array}{l}\text { Participants referred to the need } \\
\text { for standards or legal regulations } \\
\text { in the genetics applications. }\end{array}$ & 14 & $\begin{array}{l}\text { 'If conducting gene therapy is allowed, there needs to be } \\
\text { some kind of regulations by government or ministry of } \\
\text { national health.' (PT-2, S-4) }\end{array}$ \\
\hline Pop culture & $\begin{array}{l}\text { Participants referred to the films, } \\
\text { media sources, or documentaries } \\
\text { while making decisions in the } \\
\text { genetics related dilemmas }\end{array}$ & 9 & $\begin{array}{l}\text { 'I have heard many rumors from media about the medical } \\
\text { trials of these genetic applications are conducted with the } \\
\text { convicts in the prisons. The films I have watched also } \\
\text { portray similar issues. Thus, I am affected by these kinds } \\
\text { of issues.' (PT-3, S-4) }\end{array}$ \\
\hline $\begin{array}{l}\text { Technological } \\
\text { concerns }\end{array}$ & $\begin{array}{l}\text { Participants referred to their } \\
\text { technology-related concerns while } \\
\text { making decisions in the genetics } \\
\text { related dilemmas. }\end{array}$ & 8 & $\begin{array}{l}\text { 'The development of technology makes both happy and } \\
\text { concerned. I am happy for them finding cures for } \\
\text { diseases but worried about the technology might be used } \\
\text { in an unwanted way and might be resulted in unwanted } \\
\text { situations.' (PT-1- S-4) }\end{array}$ \\
\hline $\begin{array}{l}\text { Development } \\
\text { of science }\end{array}$ & $\begin{array}{l}\text { Participants referred their reliance } \\
\text { on science and scientific } \\
\text { developments while making } \\
\text { decisions in the genetics related } \\
\text { dilemmas }\end{array}$ & 8 & $\begin{array}{l}\text { 'I think the couple should not abort the fetus because any } \\
\text { new treatment might come up at any time. Science is } \\
\text { progressing rapidly. Thus, I believe treatment can be } \\
\text { developed at any time.' (PT-5, S-2) }\end{array}$ \\
\hline $\begin{array}{l}\text { Economic } \\
\text { concerns }\end{array}$ & $\begin{array}{l}\text { Participants indicated their } \\
\text { concerns about economic reasons } \\
\text { which would end up some people } \\
\text { would access the genetics } \\
\text { applications in the scenarios while } \\
\text { some people could not. }\end{array}$ & 6 & $\begin{array}{l}\text { 'If this method [referring to gene therapy] is developed, } \\
\text { then, it would be expensive. Using this method would } \\
\text { most likely be related to wealth. Then, only wealthy } \\
\text { people would use it and would be smarter.' (PT-5, S-4) }\end{array}$ \\
\hline Family bias & $\begin{array}{l}\text { Participants indicated that their } \\
\text { decision may change if the } \\
\text { situation involved themselves or } \\
\text { their family members }\end{array}$ & 5 & $\begin{array}{l}\text { 'I do make decisions in these hypothetical scenarios but I } \\
\text { do not go through these situations. My decisions can be } \\
\text { very logical when viewed outside. However, my decisions } \\
\text { may change when I, myself go through it.' (PT-4, S-4) }\end{array}$ \\
\hline $\begin{array}{l}\text { Personal } \\
\text { experience }\end{array}$ & $\begin{array}{l}\text { Participants used their previous } \\
\text { experiences while making } \\
\text { decisions in genetics related } \\
\text { dilemmas }\end{array}$ & 4 & $\begin{array}{l}\text { 'There is a family who has a child with severe disabilities } \\
\text { we know closely. The child lies down all the time. The } \\
\text { family could not provide anything needed for the child. I } \\
\text { think families should consider what they can provide to a } \\
\text { sick child while making an abortion decision.' (PT-3, S-2) }\end{array}$ \\
\hline $\begin{array}{l}\text { Ethical } \\
\text { concerns }\end{array}$ & $\begin{array}{l}\text { Participants referred that the } \\
\text { ethical aspect of genetics } \\
\text { application in the scenarios }\end{array}$ & 4 & $\begin{array}{l}\text { 'I think if that kind of treatment was really existed } \\
\text { [referring to fetal tissue transplantation], getting pregnant } \\
\text { for this treatment did not seem ethical to me.' (PT-3, S-1) }\end{array}$ \\
\hline $\begin{array}{l}\text { Need more } \\
\text { information }\end{array}$ & $\begin{array}{l}\text { Participants indicated they need } \\
\text { more information in the scenarios } \\
\text { to make decisions. }\end{array}$ & 3 & $\begin{array}{l}\text { 'I think Lale [referring to the fictitious character] should } \\
\text { abort the fetus as the disease is fatal. However, we do not } \\
\text { know many factors that are important at this point: what } \\
\text { is the economic situation of this family? or we do not } \\
\text { know anything about what Lale's husband thinks about } \\
\text { this abortion option. Thus, we need more details to make } \\
\text { a broader decision.' (PT-6, S-3) }\end{array}$ \\
\hline
\end{tabular}

'If the genetic test results show that the embryo is sick, Reyhan, and Semih [referring to the fictitious couple] should consider abortion. I am putting myself in their shoes. I decide to abort the fetus because the pain they would go through would be terrible for them.' (PT-7, S2)

When the above-presented quotations were examined, it could be seen that the participants considered the emotional situations that the families would go through in the scenarios. Especially the pain and the empathy towards the fictitious characters influenced their decisions in these scenarios.

\subsection{The Factors Influencing Pre-Service Science Teachers' Decision-Making Processes}

The second research question explored the other factors (other than moral reasoning and emotion-based reasoning) that influence pre-service teachers' decisionmaking processes in genetics-related SSI. To answer this research question, the researcher dug into the data and investigated other influential factors in participants' decisions. There were 61 statements $(21.19 \%)$ coded in this part (see Table 6). Here, there a wide range of influencing factors was revealed from the data. The most influential factor was the legal concerns reflected by participants. They 
were concerned about the need for some standard and legal regulations to create some standard procedures for applying genetics technologies $(n=14)$. They were also influenced by the films, media sources, or documentaries reflected in pop culture sub-theme $(\mathrm{n}=9)$. Some statements were showing pre-service science teachers' concerns about technology. They were concerned about the ill-usage of technology $(n=8)$. However, there were some statements showing participants' reliance on scientific developments. They showed faith in science and how scientific development can change the current treatment options for diseases $(n=8)$. Their decisions sometimes were influenced by the economic constraints that some people might not have access to the genetics application because of economic conditions $(n=6)$. Similarly, some participants indicated that their positions might change if they include themselves or their family members $(n=5)$. Even though it is not very frequent, in some scenarios, participants used their own experiences to interpret the scenarios to make decisions $(n=4)$. In a few cases, pre-service science teachers emphasized the ethical issues. For instance, one participant (PT-3) did not think it was proper to get pregnant to donate fetus' tissues for the hypothetical treatment scenario (S-1). Lastly, in a very few cases, pre-service teachers indicated that they needed more information (i.e., information about the family's economic situation or the husband's opinion about abortion) to make a more comprehensive decision $(\mathrm{n}=3)$. Table 6 presents the description of, frequency of and excerpts exemplifying each influencing factor.

\subsection{Discussion}

This study explored pre-service science teachers' moral reasoning patterns and the factors that influence their genetics-related SSI decisions. The results revealed that pre-service science teachers' decisions in genetics related SSI were heavily affected by moral considerations. This result can be an expected outcome as morality is crucial while discussing and making decisions in SSI (Zeidler \& Keefer, 2003). Existing studies also confirmed the significant role of morality while making decisions regarding SSI (Bell \& Lederman, 2003; Chang Rundgren \& Rundgren, 2010; Kar1san \& Cebesoy, 2020; Sadler, 2004a; 2004c; Sadler \& Zeidler, 2004; Zeidler \& Keefer, 2003). For instance, exploring college professors' decision-making in different SSI, Bell, and Lederman (2003) found out that $85 \%$ of their responses included ethical, moral, and value considerations. When the moral reasoning patterns were explored, pre-service science teachers' decisions were mostly influenced by genetics applications' consequences. In another study with pre-service science teachers $(n=47)$, Karisan and Cebesoy (2020) revealed that participants' decisions were mostly influenced by ethical and moral considerations $(42 \%)$. Close examination of consequentialist moral reasoning patterns revealed that participants emphasized the participant's health improvement as a significant factor influencing their decisions. Health improvement of participants was also a considerable concern for both science teachers (Cebesoy, 2014) and college students (Sadler \& Zeidler, 2004; Sadler, 2004a) decisions supporting gene therapy or other genetic applications the scenarios. Different consequentialist moral reasoning patterns including participants' concerns were disrupting natural order, creating social classes (those accessed to the genetic applications and those who cannot access) in the society and slippery slope implications of genetic applications (allowing gene therapy in one proper context might lead its use in other unacceptable contexts) and the need of a variation among society. These concerns were also frequently reported in existing studies (Cebesoy, 2014; Sadler \& Zeidler, 2004; Sadler, 2004a). Even similar patterns were found between the studies mentioned earlier and this study; some differences were also seen (Sadler \& Zeidler, 2004; Sadler, 2004a). For instance, Sadler and Zeidler (2004) reported overpopulation reflecting participants' concerns about the effects of genetic engineering application on the human population as a consequentialist moral reasoning pattern. This theme was not found in this study. In another study, Sadler (2004a) reported that college students were mostly concerned about the effects of genetic applications for others, maintaining natural order, and slippery slope concerns. Revealing different consequentialist moral reasoning patterns among various studies might be related to each study's participants were different (college students majoring in another department and in-service science teachers).

Compared to consequentialist moral reasoning patterns, pre-service science teachers' principle-based moral reasoning patterns were less referred to in their decisions. Still, pre-service teachers mostly stressed parental rights. Here, we also see two different opinions (one opinion expressing it is parents' right to choose what is best for their child and the other represents parents/individuals have no right over other individuals their children-). Besides parental rights, participants showed concern about the embryo's status as a human being and aborting the fetus to donate its tissues for medical reasons, and the need to maintain natural order. While the finding of using principle-moral reasoning patterns less in their decisions was a common finding in this study and other studies (Cebesoy, 2014; Sadler \& Zeidler, 2004), finding parental rights pattern more when compared to different patterns (a means to an end, making human life or disrupting natural order) was surprising. Existing studies reported that participants were more concerned about the embryo's status and scarifying it for medical reasons (Cebesoy, 2014; Sadler \& Zeidler, 2004). In this study, we found vice versa. This result also might be related to participant characteristics and backgrounds.

Another central theme found in pre-service science teachers' reasoning patterns was emotion-based reasoning. 
Here, participants showed empathy (i.e., statements like 'if I were her' or 'I am putting myself in their shoes') or expressed the suffering that the families/the patients would go through. The life quality of sick people influenced their decisions. This finding was also consistent with the literature stating emotions played an important role in participants' decisions indifferent SSI, including genetic applications (Cebesoy, 2014; Karisan \& Cebesoy, 2020; Sadler \& Zeidler, 2004, 2005; Sadler, 2004a; Topcu et al. 2011), nuclear power plant and generation (Lee et al. 2012; Jho, Yoon \& Kim, 2014), global warming and climate change (Lee et al. 2012; Topcu et al. 2011), organ transplantation, recycling and use of forest areas (Ozden, 2020), and stem cell research (Lee et al. 2012). Regardless of the SSI topic, emotions were found to influence participants' decisions. Moreover, Fowler, Zeidler, and Sadler (2009) argued that SSI's moral emotions are crucial to enhance functional scientific literacy. This study also confirmed that participants showed care feeling towards the fictitious characters in the scenarios regardless of the scenarios discussed.

The studies exploring participants' reasoning patterns revealed that participants sometimes showed sudden and unsupported claims while discussing SSI, which was defined as moral intuition (Cebesoy, 2014; Ozden, 2020; Sadler \& Zeidler, 2004, 2005; Topcu et al. 2011). On the contrary, this study revealed no moral intuition-based reasoning pattern among participants' responses.

The second research question of this study explored which factors (other than moral) influenced pre-service decisions. The findings revealed that participants' decisions were affected by a wide range of factors, including legal, ethical, technological, economic concerns, personal experiences, pop culture, and family bias. Overall, the literature showed that economic factors (Bell \& Lederman, 2003; Cebesoy, 2014; Chang Rundgren \& Rundgren, 2010; Karisan \& Cebesoy, 2020; Topcu et al. 2011), personal experiences (Bell \& Lederman, 2003; Cebesoy, 2014; Chang Rundgren \& Rundgren, 2010; Jho et al. 2014; Sadler \& Zeidler, 2004; Sadler, 2004a; Zeidler \& Schafer, 1984), support of science (Bell \& Lederman, 2003; Cebesoy, 2014), pop culture and family bias (Cebesoy, 2014; Sadler \& Zeidler, 2004) were influential factors for participants' decisions in SSI showing the necessity of including multiple perspectives. Indeed, existing studies also stress the importance of having multiple views of SSI-based teaching (Chang Rundgren \& Rundgren, 2010; Karisan \& Cebesoy, 2020). There were some statements showing participants' support for and faith in scientific developments in this study. This result confirms the existing literature reporting the participants showed a degree of faith in scientific developments (Bell \& Lederman, 2003; Cebesoy, 2014). Significantly few participants indicated it would be better to know more information about the scenarios to make comprehensive decisions. This finding was in line with previous studies in which participants asked for more details for making broad decisions (Cebesoy, 2014; Sadler \& Zeidler, 2004). Existing literature also reported that religious considerations were a significant factor influencing participants' decisions in various SSI (Bell \& Lederman, 2003; Cebesoy, 2014; Chang Rundgren \& Rundgren, 2010; Sadler \& Zeidler, 2004, Sadler, 2004a; Topcu et al., 2011). In contrast to this finding, the present study revealed no religious concerns stated by the preservice teachers.

\section{CONCLUSION}

The present study revealed that pre-service science teachers' decisions in genetics-related SSI are mainly influenced by consequentialist moral reasoning and emotive-based moral reasoning. They considered a wide range of consequentialism-based factors including health improvement of patients, the risk of creating subclasses in the society based on the accessibility of genetics applications, the concerns of genetics applications might be used in an unacceptable context such as beauty reasons or making people smarter, and the need of diversity in the individuals building up the society. Besides, they showed empathy and sympathy toward the characters presented in the scenarios. As a second attempt to explore if other factors influenced pre-service teachers' decisions, some factors including legal, economic, ethical, and technological concerns were revealed. Moreover, participants used their personal experiences to make decisions. Lastly, in some scenarios, participants indicated the need for more information for making comprehensive decisions. Overall, these results showed that the participants considered a wide range of factors while making genetics-related SSI decisions. All these factors during SSI-based teaching could enhance pre-service science teachers' development of decision-making skills. When the crucial role of teacher preparation for teaching SSI in their classes considered, this study has some recommendations for further research: First of all, the present study included a small number of participants to shed light on pre-service science teachers' moral reasoning and the other factors influence their decisions while dealing with genetics related SSI. The number of participants might be increased to examine if the factors (moral intuition or religious considerations) that were not revealed in this study can be revealed or not. Second, as this study confirms the need to include multiple perspectives and factors during SSI-based teaching, an intervention focusing on the inclusion of multiple perspectives can be developed to develop pre-service science teachers' decision-making skills in genetics related SSI. Lastly, this study only adopted genetics related to SSI topics. Other SSI topics, such as climate change, organ transplantation, and nuclear power plantation, can be used to explore participants' moral reasoning patterns and crosscase investigation, revealing differences in reasoning patterns among different SSI topics. 


\section{REFERENCES}

Aivelo, T., \& Uitto, A. (2019). Teachers' approaches to genetics teaching mirror their choice of content and avoidance of sensitive issues. [E-reader version]. Retrieved from http://dx.doi.org/10.1101/350710

Archibald, M. M. (2016). Investigator triangulation: A collaborative strategy with potential for mixed methods research. Journal of Mixed Methods Research, 10(3), 228-250.

Bell, R. L. (1999). Understandings of the nature of science and decision making on science and technology based issues (Unpublished doctoral dissertation). Oregon State University, Oregon.

Bell, R. L., \& Lederman, N. G. (2003). Understandings of the nature of science and decision making on science and technology based issues. Science Education, 87(3), 352-377.

Bingle, W. H., \& Gaskell, P. J. (1994). Scientific literacy for decisionmaking and the social construction of scientific knowledge. Science Education, 78(2), 185-201.

Bossér, U., Lundin, M., Lindahl, M., \& Linder, C. (2015). Challenges faced by teachers implementing socioscientific issues as core elements in their classroom practices. European Journal of Science and Mathematics Education, 3(2), 159-176.

Braun, V., \& Clarke, V. (2013). Successful qualitative research: A practical guide for beginners. Sage.

Bryce, T., \& Gray, D. (2004). Tough acts to follow: the challenges to science teachers presented by biotechnological progress. International Journal of Science Education, 26(6), 717-733.

Caelli, K., Ray, L., \& Mill, J. (2003). 'Clear as mud': Toward greater clarity in generic qualitative research. International Journal of Qualitative Methods, 2(2), 1-13.

Cebesoy, U. B. (2014). An analysis of science teachers' genetics literacy and related decision making process (Unpublished doctoral dissertation). Middle East Technical University, Ankara, Turkey.

Chang Rundgren, S. N., \& Rundgren, C. J. (2010). SEE-SEP: From a separate to a holistic view of socioscientific issues. Asia-Pacific Forum on Science Learning \& Teaching, 11(1), 1-24.

Eggert, S., Ostermeyer, F., Hasselhorn, M., \& Bögeholz, S. (2013). Socio-scientific decision making in the science classroom: The effect of embedded metacognitive instructions on students' learning outcomes. Education Research International, 1-12.

Fowler, S. R., \& Zeidler, D. L. (2016). Lack of evolution acceptance inhibits students' negotiation of biology-based socioscientific issues. Journal of Biological Education, 50(4), 407-424.

Fowler, S. R., Zeidler, D. L., \& Sadler, T. D. (2009). Moral sensitivity in the context of socioscientific issues in high school science students. International Journal of Science Education, 31(2), 279-296.

Gericke, N., \& Smith, M. (2014). Twenty-first-century genetics and genomics: Contributions of HPS-informed research and pedagogy. In M. R. Matthews (Ed.), International Handbook of Research in History, Philosophy and Science teaching (pp. 423-467). Springer.

Gresch, H., Hasselhorn, M., \& Bögeholz, S. (2017). Enhancing decisionmaking in STSE education by inducing reflection and self-regulated learning. Research in Science Education, 47(1), 95-118.

Guion, R. M. (2002). Validity and reliability. In S. G. Rogelberg (Ed.), Handbook of Research Methods in Industrial- Organizational Psychology (pp. 57-76). Blackwell.

Hsu, Y. S., \& Lin, S. S. (2017). Prompting students to make socioscientific decisions: embedding metacognitive guidance in an e-learning environment. International Journal of Science Education, 39(7), 964-979.

Jho, H., Yoon, H. G., \& Kim, M. (2014). The relationship of science knowledge, attitude and decision making on socioscientific issues: The case study of students' debates on a nuclear power plant in Korea. Science \& Education, 23(5), 1131-1151.

Kahlke, R. M. (2014). Generic qualitative approaches: Pitfalls and benefits of methodological mixology. International Journal of Qualitative Methods, 13(1), 37-52.

Karisan, D., \& Cebesoy, U. B. (2020). Use of the SEE-SEP model in preservice science teacher education: The case of genetics dilemmas. In W. A.
Powell (Ed.), Socioscientific Issues-Based Instruction for Scientific Literacy Development (pp. 223-254). IGI Global.

Khishfe, R. (2014). Explicit nature of science and argumentation instruction in the context of socioscientific issues: An effect on student learning and transfer. International Journal of Science Education, 36(6), 974-1016.

Lee, H., Chang, H., Choi, K., Kim, S. W., \& Zeidler, D. L. (2012). Developing character and values for global citizens: Analysis of pre-service science teachers' moral reasoning on socioscientific issues. International Journal of Science Education, 34(6), 925-953.

Maxwell, J. A. (2012). Qualitative research design: An interactive approach (Vol. 41). Sage Publications

Merriam, S. B. (2009). Qualitative research: A guide to design and implementation (3rd Ed.). Jossey-Bass.

Miles, M. B., \& Huberman, A. M. (1994). Qualitative data analysis: An expanded sourcebook (2nd Ed.). Sage Publications.

Ministry of National Education [MoNE]. (2018). Primary science and technology curriculum for 3 th-8th grades. [E-reader version]. Retrieved from http://mufredat.meb.gov.tr/ProgramDetay.aspx?PID=325

National Academies of Sciences, Engineering, and Medicine. (2016). Science literacy: Concepts, contexts, and consequences. The National Academies Press.

Organisation for Economic Co-operation and Development [OECD]. (2012). Assessment and Analytical Framework. [E-reader version]. Retrieved from https://www.oecd.org/pisa/pisa-fordevelopment/PISA-D-Assessment-and-Analytical-FrameworkEbook.pdf

Ozden, M. (2020). Elementary school students' informal reasoning and its' quality regarding socioscientific issues. Eurasian Journal of Educational Research, 86, 61-84.

Percy, W. H., Kostere, K., \& Kostere, S. (2015). Generic qualitative research in psychology. The Qualitative Report, 20(2), 76-85.

Rundgren, C. J., \& Chang Rundgren, S. N. (2018). Aiming for responsible and competent citizenship through teacher professional development on teaching socioscientific inquiry-based learning (SSIBL). Asia-Pacific Forum on Science Learning and Teaching, 19(2), Article 2.

Sadler, T. D. (2004a). Moral sensitivity and its contribution to the resolution of socioscientific issues. Journal of Moral Education, 33(3), 339-358.

Sadler, T. D. (2004b). Moral and ethical dimensions of socioscientific decision-making as integral components of scientific literacy. The Science Educator, 13, 39-48.

Sadler, T.D. (2004c). Informal reasoning regarding socioscientific issues: A critical review of the literature. Journal of Research in Science Teaching, 4, 513-536.

Sadler, T. D., \& Donnelly, L. A. (2006). Socioscientific argumentation: The effects of content knowledge and morality. International Journal of Science Education, 28(12), 1463-1488.

Sadler, T. D. \& Zeidler, D. L. (2004). The morality of socioscientific issues: Construal and resolution of genetic engineering dilemmas. Science Education, 88, 4-27.

Sadler, T. D., \& Zeidler, D. L. (2005). Patterns of informal reasoning in the context of socioscientific decision making. Journal of Research in Science Teaching, 42(1), 112-138.

Sadler, T. D., Amirshokoohi, A., Kazempour, M., \& Allspaw, K. M., (2006). Socioscience and ethics in science classrooms: Teacher perspectives and strategies. Journal of Research in Science Teaching, 43(4), 353-376.

Teddlie, C., \& Tashakkori, A. (2009). Foundations of mixed methods research: Integrating quantitative and qualitative approaches in the social and behavioral sciences. Sage Publications.

Topcu, M. S. (2008). Pre-service science teachers' informal reasoning regarding socioscientific issues and the factors influencing their informal reasoning (Unpublished doctoral dissertation). Middle East Technical University, Ankara.

Topcu, M. S., Yılmaz-Tüzün, Ö., \& Sadler, T. D. (2011). Turkish preservice science teachers' informal reasoning regarding 
socioscientific issues and the factors influencing their informal reasoning. Journal of Science Teacher Education, 22(4), 313-332.

Walker, K. A., \& Zeidler, D. L. (2007). Promoting discourse about socioscientific issues through scaffolded inquiry. International Journal of Science Education, 29(11), 1387-1410.

Zeidler, D. L., \& Keefer, M. (2003). The role of moral reasoning and the status of socioscientific issues in science education. In D. L. Zeidler (Ed.), The Role of Moral Reasoning on Socioscientific Issues and Discourse in Science Education (pp. 7-38). Springer.

Zeidler, D. L., \& Schafer, L. E. (1984). Identifying mediating factors of moral reasoning in science education. Journal of Research in Science Teaching, 21(1), 1-15.

Zeidler, D. L., Sadler, T. D., Applebaum, S., \& Callahan, B. E. (2009). Advancing reflective judgment through socioscientific issues. Journal of Research in Science Teaching, 46(1), 74-101.

Zohar, A., \& Nemet, F. (2002). Fostering students' knowledge and argumentation skills through dilemmas in human genetics. Journal of Research in Science Teaching, 39(1), 35-62. 